\title{
Lactate clearance for death prediction in severe sepsis or septic shock patients during the first 24 hours in Intensive Care Unit: an observational study
}

Philippe Marty ${ }^{1 *}$, Antoine Roquilly², Fabrice Vallée ${ }^{1}$, Aymeric Luzi ${ }^{1}$, Fabrice Ferré ${ }^{1}$, Olivier Fourcade ${ }^{1}$, Karim Asehnoune ${ }^{2}$ and Vincent Minville ${ }^{1}$

\begin{abstract}
Background: This study was design to investigate the prognostic value for death at day-28 of lactate course and lactate clearance during the first 24 hours in Intensive Care Unit (ICU), after initial resuscitation.

Methods: Prospective, observational study in one surgical ICU in a university hospital. Ninety-four patients hospitalized in the ICU for severe sepsis or septic shock were included. In this septic cohort, we measured blood lactate concentration at ICU admission ( $\mathrm{HO}$ ) and at $\mathrm{H6}, \mathrm{H} 12$, and $\mathrm{H} 24$. Lactate clearance was calculated as followed: [(lactate initial - lactate $\left._{\text {delayed }}\right) /$ lactate $\left.\left._{\text {initial }}\right] \times 100 \%\right]$.

Results: The mean time between severe sepsis diagnosis and HO (ICU admission) was $8.0 \pm 4.5$ hours. Forty-two (45\%) patients died at day 28. Lactate clearance was higher in survivors than in nonsurvivors patients for $\mathrm{HO}-\mathrm{H} 6$ period $(13 \pm 38 \%$ and $-13 \pm 7 \%$ respectively, $p=0.021)$ and for the $\mathrm{HO}-\mathrm{H} 24$ period $(42 \pm 33 \%$ and $-17 \pm 76 \%$ respectively, $p<0.001)$. The best predictor of death at day 28 was lactate clearance for the $\mathrm{HO}-\mathrm{H} 24$ period (AUC = $0.791 ; 95 \% \mathrm{Cl}$ 0.6-0.85). Logistic regression found that $\mathrm{HO}-\mathrm{H} 24$ lactate clearance was independently correlated to a survival status with a $p=0.047$ [odds ratio $=0.35(95 \% \mathrm{Cl} 0.01-0.76)$ ].
\end{abstract}

Conclusions: During the first $24 \mathrm{hr}$ in the ICU, lactate clearance was the best parameter associated with 28-day mortality rate in septic patients. Protocol of lactate clearance-directed therapy should be considered in septic patients, even after the golden hours.

Keywords: Sepsis, Lactate, Lactate clearance, Prognostic factor, Goal-directed therapy

\section{Background}

Severe sepsis and septic shock are a leading cause of death in the world [1]. An early strategy of quantitative resuscitation enables a decrease in mortality rate of septic patients, but few data are available for prolonged intensive care unit (ICU) strategy [2,3]. Despite the international recommendation of an early goal-directed therapy [4], based on optimization of mean arterial pressure, central venous pressure, urine output, and central

\footnotetext{
* Correspondence: philippemarty@hotmail.com

'Department of Anesthesiology and Intensive Care, CHU Toulouse, Université Toulouse III Paul Sabatier, Faculté de Médecine Toulouse-Rangueil, EA 4564MATN, Institut Louis Bugnard (IFR 150), c F-31000, France

Full list of author information is available at the end of the article
}

venous oxygen saturation $\left(\mathrm{ScvO}_{2}\right)$, mortality rate remains high in septic shock [5-7]. There is a need to test the prognostic value of factors that could be used for guiding therapy after the initial resuscitation.

Static blood lactate concentrations have already been tested in this purpose. In case of circulatory failure, such as severe sepsis, lactate concentration is a complex result of an anaerobic production, an aerobic production via the $\mathrm{Na}-\mathrm{K}$ ATPase channel, and a decrease in lactate utilization [8-11]. However, several studies have described a correlation between baseline lactate concentration and mortality of ICU patients [12-15]. Although informative for severity assessment of septic patients, basal lactate rate is useless to guide therapy of such patients. Recently, lactate clearance 
in the first 6 hours was associated with an improvement of outcome in severe sepsis and septic shock patients and was proposed to guide treatment [16]. Lactate clearance as a goal of early sepsis therapy (in the first 6 hours), compared with central venous saturation, did not reduce the mortality of septic patients [17]. Longer duration of lactate clearance monitoring might result in better results, but there is a lack of data regarding lactate clearance in ICU after the first 6 hours of treatment for sepsis.

We hypothesized that lactate clearance at arrival in intensive care unit (after the golden hours in the emergency department) could remain predictive for outcomes. Thus, we investigated the prognostic value for death of lactate concentration, lactate clearance, and parameters derived from $\mathrm{ScvO}_{2}$ during the first 24 hours in ICU.

\section{Materials and methods}

\section{Setting}

According to French legislation (articles L.1121-1 paragraph 1 and R1121-2, Public Health Code), no informed consent is needed to use data for an observational study and informed consent from patients or relatives was waived by the institutional review board. No change in our current clinical practice (all measurements were routinely required in septic shock patients) and no randomization was performed.

\section{Design of the study}

The study was a prospective, observational case series of adult patients. The study was conducted from April 2006 to may 2007 in a 16-bed University Hospital ICU. Consecutive patients admitted in this ICU for severe sepsis or septic shock, who were from the emergency department, were screened for the study. According to international recommendations [4], sepsis was defined as infection plus at least two criteria of systemic inflammation response. Severe sepsis was defined as sepsis plus sepsis-induced organ dysfunction or tissue hypoperfusion. Septic shock was defined as sepsis-induced hypotension (systolic blood pressure $<90 \mathrm{mmHg}$ or mean arterial pressure $<70 \mathrm{mmHg}$ ) persisting despite adequate fluid resuscitation. A blood lactate concentration above $4 \mathrm{mmol} . \mathrm{l}^{-1}$ or oliguria $(<0.5 \mathrm{ml}$. $\mathrm{hr}^{-1}$ ) defined hypoperfusion. Exclusion criteria were age $\leq 18$ years, pregnancy, and ICU-acquired severe sepsis.

Patient management in the emergency department was performed as recommended in the international guidelines for septic shock [4]. The inclusion of the patient in our study began at the arrival in the ICU (H0), i.e., after the initial management in the emergency department. Patient management in intensive care unit was gone on to reach the international guidelines goals during the first $24 \mathrm{hr}$ hospitalization [4]: 1) mean arterial pressure (MAP) $\geq 65 \mathrm{mmHg}$ and diastolic arterial pressure (DAP) $\geq 40 \mathrm{mmHg}$; 2) $\mathrm{ScvO}_{2} \geq 70 \%$; (3) urine output $\geq 0.5$ $\mathrm{ml} / \mathrm{kg} / \mathrm{hr}$.

Our standard septic shock resuscitation treatment was administrated in sequence until the following goals were reached:

1. Diagnosis of septic shock with lactate measurement followed by $30-40 \mathrm{ml} / \mathrm{kg}$ crystalloid fluid loading over 1 hour.

2. Norepinephrine titrated to obtain a MAP $\geq 65 \mathrm{mmHg}$ and a DAP $\geq 40 \mathrm{mmHg}$.

3. $\mathrm{ScvO}_{2}$ measurement: fluid loading of $500 \mathrm{ml}$ crystalloid and/or colloid every $10 \mathrm{~min}$ until $\mathrm{ScvO}_{2}$ reached a value $\geq 70 \%$.

4. Blood transfusion if $\mathrm{ScvO}_{2}$ remained $\leq 70 \%$ and hematocrit $(\mathrm{Ht}) \leq 30 \%$.

5. Dobutamine at a dose of $5 \mu \mathrm{g} / \mathrm{kg} / \mathrm{min}$ if $\mathrm{Ht} \geq 30 \%$ and $\mathrm{ScvO}_{2} \leq 70 \%$.

6. After $6 \mathrm{hr}$ when lactate level remained higher than 2 mmol/l: cardiac output was measured by a Pulse Indexed Continuous Cardiac Output (PiCCo) monitor (Pulsion, Medical Systems AG, Munich, Germany) to optimize oxygen delivery $\left(\mathrm{DO}_{2}\right)$ and reach an $\mathrm{ScvO}_{2} \geq 70 \%$ : successive colloid "fluid challenge" of $500 \mathrm{ml}$ over $15 \mathrm{~min}$ until CI variation during the challenge became less than $15 \%$, transfusion if $\mathrm{Ht} \leq 30 \%$ and $\mathrm{ScvO}_{2} \leq 70 \%$, dobutamine if $\mathrm{ScvO}_{2}$ remained lower than $70 \%$.

7. If $\mathrm{ScvO}_{2}$ remained lower than $70 \%$ after this $\mathrm{DO} 2$ optimization, attempts to lower oxygen consumption were instituted (fever control and/or mechanical ventilation after tracheal intubation and/or increase in sedation and/or pain medication).

Others procedures within the first $24 \mathrm{hr}$ :

1. After bacterial samples, eradication of any septic focus with early empiric broad-spectrum antibiotics and surgery when needed.

2. Prescription of low dose hydrocortisone if patients were treated by norepinephrine for more than $6 \mathrm{hr}$ as recommended [4].

\section{Data collection}

Diagnosis, age, gender, and calculated Simplified Apache Physiology Score (SAPS 2) were prospectively recorded. Blood lactate concentration, mean arterial pressure, cardiac index assessed with $\mathrm{PiCCO}^{\circledR}$, arterial oxygen saturation $\left(\mathrm{SaO}_{2}\right)$ measured on arterial blood gas, $\mathrm{ScvO}_{2}$ measured on a central venous blood sample (superior vena cava) were collected when patients arrived in ICU (H0) and successively at 6, 12, and 24 hours after admission (H6, H12, and H24 after the ICU admission). 
Survival was followed-up during 28 days. As previously described $[16,17]$, the lactate clearance was defined by the equation [(lactate initial $_{\text {- }}$ lactate $\left._{\text {delayed }}\right) /$ lactate $\left._{\text {initial }}\right] \times$

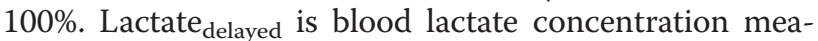
sured at $\mathrm{H} 6, \mathrm{H} 12$, or $\mathrm{H} 24$. A positive value indicates a decrease in lactate rate. $\mathrm{ScvO}_{2}$ variation was defined by the equation $\left[\left(\mathrm{ScvO}_{2 \text { delayed }}-\mathrm{ScvO}_{2 \text { initial }}\right) / \mathrm{ScvO}_{2 \text { initial }}\right] \times$ $100 \%$. Time of inclusion (H0) and study enrolment were considered as the time of ICU admission. The transit time in the emergency room between diagnosis of septic shock and enrollment in ICU was registered.

\section{Statistical analysis}

Quantitative variables are presented as mean \pm SD and qualitative data are given as number and percentage. Normal distribution of data was tested via KolmogorovSmirnov test. The values results were not normally distributed and thus were analyzed non-parametrically.

Survivors and nonsurvivors were compared by the Mann-Whitney $U$ test for continuous variables and by Fisher's exact test for categorical variables. To assess whether the lactates changed over time, Friedman's test was used. When Friedman's test was significant $(p<0.05)$, pairwise comparisons were made using Wilcoxon's signed-rank test. All tests were two-sided, and $p<0.05$ indicated a statistical significance. Because lactate and $\mathrm{SvcO}_{2}$ are numerical data, receiver-operating characteristics (ROC) curves and area under the curve (AUC) were computed. For mortality prediction, cutoff values for lactates, lactate clearance, and $\mathrm{SvcO}_{2}$ were chosen to correspond to the best respective Youden's index calculated as follows: Youden's index = sensitivity + specificity -1 . Results are expressed for area under the ROC curves (AUC) as mean (95\% confidence interval).
A logistic regression was performed to discriminate if SAPS II, lactate at $\mathrm{H} 0, \mathrm{H} 6, \mathrm{H} 12$, and $\mathrm{H} 24$, lactate clearance $\mathrm{H} 0-\mathrm{H} 6, \mathrm{H} 0-\mathrm{H} 12$, and $\mathrm{H} 0-\mathrm{H} 24$, and norepinephrine were independently correlated to the survival status. Goodness of fit of the model was assessed using the Hosmer-Lemeshow test. Statistical analysis was realized by SAS 9.1.3 software.

\section{Results}

\section{Patient characteristics}

From April 2006 to May 2007, 96 septic shock patients who were admitted in the ICU and who had been previously resuscitated in the emergency unit were considered eligible. Two patients were excluded (one for pregnancy and one for age $<18$ years). The mean time between severe sepsis diagnose and H0 (ICU admission) was $8.0 \pm 4.5$ hours.

We analyzed the data of 94 patients with severe sepsis or septic shock. Demographic data are provided in Table 1. All of the patients received sedation (Ramsay score between 3 and 5) and were mechanically ventilated. Norepinephrine was used in all patients. Thirtyone patients were treated with dobutamine. Forty-two (45\%) patients died in the first 28 days. The mean SAPS 2 was $53 \pm 16$ in survivors versus $69 \pm 15$ in nonsurvivor patients $(p<0.01)$. No statistical difference was noticed for MAP and CO between survivors and nonsurvivors at any time.

\section{Static blood lactate and lactate clearance in survivors and non survivors}

The static blood lactate and lactate clearance are illustrated in Figure 1. There is a significant difference

\section{Table 1 Demographic characteristics}

\begin{tabular}{|c|c|c|c|}
\hline & Overall population $(\mathrm{N}=94)$ & Survivors $(N=52)$ & Nonsurvivors $(\mathrm{N}=42)$ \\
\hline \multicolumn{4}{|l|}{ Gender } \\
\hline$M / F(\%)$ & $56 / 44$ & 59 / 41 & $54 / 46$ \\
\hline Age $(y r)($ mean \pm SD) & $58 \pm 16$ & $55 \pm 17$ & $61 \pm 15$ \\
\hline SAPS $2($ mean \pm SD) & $60 \pm 17$ & $53 \pm 16$ & $69 \pm 15^{*}$ \\
\hline \multicolumn{4}{|l|}{ Sepsis origin, N (\%) } \\
\hline Pulmonary & $27(29)$ & $14(27)$ & $13(31)$ \\
\hline Digestive & $26(28)$ & $18(35)$ & $8(19)$ \\
\hline Urinary & $4(4)$ & $2(4)$ & $2(5)$ \\
\hline Other & $37(39)$ & $18(35)$ & $19(45)$ \\
\hline \multicolumn{4}{|c|}{ Hemodynamic status on ICU admission (mean \pm SD) } \\
\hline Mean arterial pressure (mmHg) & $66.5 \pm 10.3$ & $68 \pm 11$ & $64 \pm 10$ \\
\hline Cardiac index $\left(\mathrm{L} / \mathrm{min} \cdot \mathrm{m}^{2}\right)$ & $3.4 \pm 1$ & $3.4 \pm 0.9$ & $3.4 \pm 1.3$ \\
\hline Norepinephrine ( $\mu \mathrm{g} / \mathrm{kg} / \mathrm{min})$ & $0.62 \pm 0.37$ & $0.44 \pm 0.34$ & $0.77 \pm 0.5^{*}$ \\
\hline $\mathrm{ScvO}_{2}(\%)$ & $73.3 \pm 9.4$ & $74.1 \pm 9.2$ & $72.3 \pm 9.6$ \\
\hline
\end{tabular}

ICU intensive care unit; SAPS 2 Simplified Acute Physiology Score; $\mathrm{ScVO}_{2}$ central venous oxygen saturation. ${ }^{*} p<0.05$ vs. survivors. 
between $\mathrm{H} 0$ lactate value and $\mathrm{H} 6, \mathrm{H} 12$, or $\mathrm{H} 24$ lactate value in survivor group $(p<0.05$ for each studied period). No significant difference was found in nonsurvivor group between $\mathrm{H} 6, \mathrm{H} 12$, and $\mathrm{H} 24$ lactate value compared with H0. Mean blood lactate concentrations were lower in survivors than in nonsurvivors patients at $\mathrm{HO}$ $(5 \pm 3.1 \mathrm{mmol} / \mathrm{L}$ vs. $6.9 \pm 4.3 \mathrm{mmol} ; p=0.049)$. Afterward, blood lactate concentrations were lowers in survivors than in nonsurvivors at each studied time $(4.1 \pm 3.2$ vs. $6.9 \pm 4.3$ at $\mathrm{H} 6 ; 3.6 \pm 2.9$ vs. $6.7 \pm 4$ at $\mathrm{H} 12$ and $3 \pm 3$ vs. $6.4 \pm 4.5$ at H24. $p<0.05$ for each studied period). Lactate clearance was $13 \pm 38 \%$ in survivors and $-13 \pm$ $67 \%$ in nonsurvivors patients for the H0-H6 period ( $p=$ 0.021 ) and remained higher in survivors than in nonsurvivors for each studied period $(42 \pm 33 \%$ vs. $-17 \pm 76 \%$; $p<0.001$ for the H0-H24 period).

\section{Static $\mathrm{SvcO}_{2}$ and $\mathrm{SvcO}_{2}$ variation in survivors and nonsurvivors}

The $\mathrm{SvcO}_{2}$ course is illustrated in Table 2. $\mathrm{SvcO}_{2}$ was not statistically different in survivors than in nonsurvivors patients at $\mathrm{H} 0$ and at each studied time. No significant $\mathrm{SvcO}_{2}$ variation was noticed for any period.

\section{Diagnostic Value of static blood lactate levels, blood} lactate clearance and central venous saturation

For each period, ROC curves, AUC for lactate, and $\mathrm{SvcO}_{2}$ were calculated (Table 3). For each period, the most accurate cutoff value to distinguish survivors and nonsurvivors was evaluated (Table 3). Best ROC curves AUC were obtained for $\mathrm{H} 24$ static blood lactate (0.773; 95\% CI 0.64-0.87) and H0-H24 lactate clearance (0.791; 95\% CI 0.6-0.85). Scv0 ${ }_{2}$-related ROC curves AUC

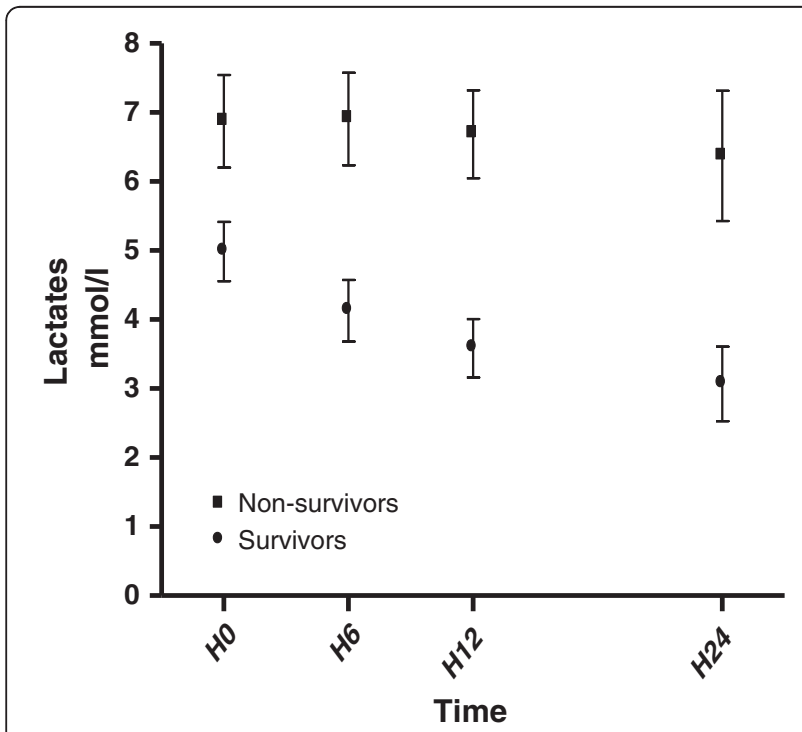

Figure 1 Time course of lactates in ICU.
Table 2 Blood lactate concentrations and lactate clearances in survivors and non survivors during the first 24 hours in ICU

\begin{tabular}{|c|c|c|c|}
\hline & Survivors & Nonsurvivors & $p$ \\
\hline $\mathrm{ScvO}_{2} \mathrm{HO}(\%)$ & $74.1 \pm 9.2$ & $72.3 \pm 11.6$ & 0.39 \\
\hline $\mathrm{ScvO}_{2} \mathrm{H} 6(\%)$ & $76.2 \pm 7.1$ & $75.2 \pm 10.9$ & 0.57 \\
\hline $\mathrm{ScvO}_{2} \mathrm{H} 12$ (\%) & $76.4 \pm 7.2$ & $73 \pm 11.5$ & 0.07 \\
\hline $\mathrm{ScvO}_{2} \mathrm{H} 24(\%)$ & $76.1 \pm 7.5$ & $76 \pm 10.8$ & 0.9 \\
\hline Variation $\mathrm{ScvO}_{2} \mathrm{H0}-\mathrm{H} 6(\%)$ & $4.19 \pm 9.4$ & $4.4 \pm 14.2$ & 0.93 \\
\hline Variation $\mathrm{ScvO}_{2} \mathrm{HO}-\mathrm{H} 12$ (\%) & $2.9 \pm 11.6$ & $3.4 \pm 10.8$ & 0.83 \\
\hline Variation $\mathrm{ScvO}_{2} \mathrm{HO}-\mathrm{H} 24$ (\%) & $3.6 \pm 14.9$ & $6.5 \pm 15.8$ & 0.5 \\
\hline
\end{tabular}

$\mathrm{ScvO}_{2}$ variation was defined by the equation $\left[\left(\mathrm{ScvO}_{2 \text { delayed }}-\mathrm{ScvO}_{2 \text { initial }}\right) /\right.$ $\left.\mathrm{ScvO}_{\text {2initial }}\right] \times 100 \%$. Results expressed as mean $\pm \mathrm{SD}$. Pairwise comparisons were made using Mann-Whitney $U$ test.

revealed a very poor ability to predict day- 28 mortality at any time.

\section{Multivariate analysis between the deceased and the survivors}

Logistic regression found that only the lactate clearance $\mathrm{H} 0-\mathrm{H} 24$ and norepinephrine were independently correlated to a survival status with a $p=0.047$ [odds ratio $=$ 0.35 (95\% CI 0.01-0.76)] and $p=0.038$ [odds ratio $=$ 2.59 (95\% CI 1.05-6.41)] respectively (Table 4).

\section{Discussion and conclusions}

The current results, obtained in a population of severe sepsis or septic shock patients, indicate and the prognostic value of lactate clearance in the first $24 \mathrm{hr}$ in ICU. After initial resuscitation, $\mathrm{ScvO}_{2}$ may have poor ability to predict death at day 28 .

Mixed central venous oxygen saturation is correlated to the central venous saturation and has been independently associated with mortality in septic shock, with threshold values supporting those published in guidelines [18]. In Varpula's study a $\mathrm{SvcO}_{2}<70 \%$ is independently associated with mortality. Moreover, even if it remains controversial, early goal-directed therapy (H0H6) adapted to a target of $\mathrm{ScvO}_{2}$ has decreased the mortality rate in septic shock patients [19].

In the current study, neither static $\mathrm{ScvO}_{2}$ nor $\mathrm{ScvO}_{2}$ variation were predictive for death at day 28 at any time. Other studies performed in intensive care unit after initial resuscitation support these data [20,21].

These different results are not contradictory. $\mathrm{ScvO}_{2}$ appears to be a useful tool for initial resuscitation but is unable to distinguish survivors and nonsurvivors after this stage. Moreover, if $\mathrm{SvcO}_{2}<70 \%[18,19]$ is associated with mortality, it does not mean that $\mathrm{SvcO}_{2} \geq 70 \%$ is associated with survival [22]. $\mathrm{ScvO}_{2}$ seems to be a necessary but not sufficient parameter to guide therapeutic intervention in ICU after initial resuscitation. In ICU- 
Table 3 Area under the ROC curves for static lactate rates and lactate clearances

\begin{tabular}{|c|c|c|c|c|c|c|c|}
\hline & AUC & IC $95 \%$ & Threshold & Se.\% & $\mathrm{Cl} 95 \%$ & Sp.\% & $\mathrm{Cl} 95 \%$ \\
\hline $\mathrm{ScvO}_{2} \mathrm{HO}$ & 0.55 & $0.44-0.66$ & $74 \%$ & 53.19 & $38.1-67.9$ & 64.86 & $47.5-79.8$ \\
\hline $\mathrm{ScvO}_{2} \mathrm{H} 6$ & 0.498 & $0.39-0.61$ & $79 \%$ & 72.34 & $57.4-84.4$ & 42.11 & $26.3-59.2$ \\
\hline $\mathrm{ScvO}_{2} \mathrm{H} 12$ & 0.609 & $0.5-0.71$ & $71 \%$ & 88.89 & 75.9-96.3 & 36.84 & $21.8-54$ \\
\hline $\mathrm{ScvO}_{2} \mathrm{H} 24$ & 0.501 & $0.36-0.64$ & $67 \%$ & 90.32 & 74.2-97.8 & 29.17 & $12.7-51.1$ \\
\hline Variation $\mathrm{ScvO}_{2} \mathrm{HO}-\mathrm{H} 6$ & 0.533 & $0.42-0.65$ & $2.5 \%$ & 54.55 & $38.9-69.6$ & 58.82 & $40.7-75.3$ \\
\hline Variation $\mathrm{ScvO}_{2} \mathrm{HO}-\mathrm{H} 12$ & 0.501 & $0.38-0.62$ & $-5.2 \%$ & 28.57 & $15.7-44.6$ & 85.29 & 68.9-95 \\
\hline Variation $\mathrm{ScvO}_{2} \mathrm{H} 0-\mathrm{H} 24$ & 0.598 & $0.45-0.73$ & $4.2 \%$ & 65.52 & $45.7-82$ & 54.55 & $32.2-75.6$ \\
\hline Lactates HO & 0.613 & $0.5-0.71$ & $5.4 \mathrm{mmol} / \mathrm{l}$ & 76.92 & $63.2-87.5$ & 54.76 & $38.7-70.1$ \\
\hline Lactates $\mathrm{H} 6$ & 0.706 & $0.6-0.8$ & $4.05 \mathrm{mmol} / \mathrm{l}$ & 63.46 & $49-76.4$ & 75.61 & $59.7-87.6$ \\
\hline Lactates $\mathrm{H} 12$ & 0.729 & $0.62-0.82$ & $4.2 \mathrm{mmol} / \mathrm{l}$ & 75 & $60.4-86,3$ & 66.67 & $49.8-80.9$ \\
\hline Lactates H24 & 0.773 & $0.64-0.87$ & $2.6 \mathrm{mmol} / \mathrm{l}$ & 67.74 & $48.6-83.3$ & 82.61 & $61.2-94.9$ \\
\hline Lac Clear H0-H6 & 0.619 & $0.5-0.72$ & $-7.7 \%$ & 63.46 & $49-76.4$ & 56.1 & $39.8-71.5$ \\
\hline Lac Clear H0-H12 & 0.662 & $0.55-0.76$ & $-44.6 \%$ & 45.83 & $31.4-60.8$ & 82.05 & $66.5-92.4$ \\
\hline Lac Clear H0-H24 & 0.791 & $0.6-0.85$ & $-2.1 \%$ & 96.77 & $83.2-99.5$ & 52.17 & $30.6-73.2$ \\
\hline
\end{tabular}

AUC area under the curve; $\mathrm{Cl}$ confidence interval; Se sensibility; Sp specificity; Lac Clear lactate clearance.

resuscitated patients, $\mathrm{ScvO}_{2}$ or mixed venous oxygen saturation is often larger than $70 \%$ despite evidence of abnormal tissue oxygenation. This oxygen extraction defects might be related to severe microcirculatory disorders [23] and/or mitochondrial damage and/or impairment of cellular respiration [24] resulting in most of the cases in elevated $\mathrm{ScvO}_{2}$ or $\mathrm{SvO} 2$ values [21,25]. Low levels reflect 1) an inadequate cardiac output with an excessive extraction of oxygen, 2) a low hemoglobin concentration, and/or 3) a low level of arterial oxygen pressure $\left(\mathrm{PaO}_{2}\right)$. In contrast, high levels of $\mathrm{ScvO}_{2}$ means either 1) a very high oxygen delivery in excess of tissue requirements, and/or 2) decreased cellular consumption of oxygen (mitochondrial dysfunction), and/or 3) more rarely, a large arteriovenous shunt [26]. After early resuscitation, $\mathrm{ScvO}_{2}$ therefore may not be sufficient to guide titration of fluid loading and vasopressor therapy.

Table 4 Multivariate analysis between the deceased and the survivors

\begin{tabular}{lllcc}
\hline \multicolumn{1}{c}{ Data } & $\boldsymbol{p}$ & $\begin{array}{l}\text { Odd } \\
\text { ratio }\end{array}$ & \multicolumn{2}{c}{$\mathbf{9 5 \% ~ C l}$} \\
\cline { 4 - 5 } & & 1.57 & 0.55 & 4.45 \\
\hline Lactates H0 & 0.4 & 0.53 & 0.09 & 3.08 \\
Lactates H6 & 0.48 & 5.3 & 0.48 & 59 \\
Lactates H12 & 0.17 & 0.23 & 0.03 & 1.61 \\
Lactates H24 & 0.14 & 2.19 & 0.27 & 83.06 \\
Lactates $\mathrm{Cl} \mathrm{H0-H6}$ & 0.61 & 9.89 & 0.05 & 90.15 \\
Lactates $\mathrm{Cl} \mathrm{H0-H12}$ & 0.1 & 0.35 & 0.01 & 0.76 \\
Lactates $\mathrm{Cl} \mathrm{H0-H24}$ & 0.047 & 1.03 & 0.96 & 1.1 \\
SAPS 2 & 0.47 & 2.59 & 1.05 & 6.41 \\
Norepinephrine & 0.038 & &
\end{tabular}

Goodness of fit was 0.73 with the Hosmer-Lemeshow test.
In a general ICU population, basal lactate concentration predicted the risk of death with a good accuracy [27]. In 2005, Varpula et al. analyzed hemodynamic parameters in septic shock patients and initial lactate concentration was higher in nonsurvivors (3.4 vs. $2.1 \mathrm{mmol} /$ 1 respectively, $p<0.005$ ) [18]. In a heterogeneous population of septic patients, blood lactate values, with a threshold of $4 \mathrm{mmo} / \mathrm{l}$, were associated with in-hospital mortality but the predictive value was poor (reported AUC under the ROC curves $=0.56$ ). The lactate concentrations were lower in survivors than in nonsurvivors all along the first $24 \mathrm{hr}$ in ICU and lactate level at H0, even with a threshold of $6.2 \mathrm{mmo} / \mathrm{l}$, indicating therefore a poor ability for death prediction in septic patients.

Several authors have reported that septic patients with the lowest lactate value at $\mathrm{H} 24$, even with the same initial lactate concentration, had the highest survival rate [28-30]. For Bakker et al., the "Lactime," defined as the time passed with a lactate rate above a normal value, was more predictive for death than the initial lactate value [31]. In a cardiac arrest-resuscitated population, lactate levels at admission were not altered in survivors and nonsurvivors patients, whereas lactate clearances were superior in survivors [32]. In hemodynamically stable surgical patients, the association of an occult hypoperfusion with a prolonged hyperlactatemia has been associated with an increased mortality rate [14]. Dynamic assessment of metabolic values may be more efficient for death prediction than static values. Several studies, in severe septic patients, pointed out the value of blood lactate clearance in the first 6 hours of resuscitation for the prediction of day-28 survival [16,33], but no data are available for longer duration. In the current study, delta lactates until the $24^{\text {th }}$ hour in ICU were 
predictive for death. Finally, the calculation and interpretation of lactate clearance appeared useful even after the "golden hours" [3,4] and enable detection of patients with a high risk of death.

For septic patients, a lactate clearance-directed therapy in the first 6 hours appeared as efficient as $\mathrm{ScvO}_{2}$ [17]. In a general ICU population, an 8-hour therapy adaptation to lactate clearance reduced the mortality rate in patients with hyperlactatemia compared with standard therapy [34]. No data are available for lactate-directed therapy for longer duration, and no target can thus be proposed. In the study of Jansen et al., a resuscitation adapted to a target of $20 \%$ decrease $/ 2$ hours for 8 hours decreased the mortality rate [34]. In another recent study, the addition of lactate clearance to the SSC resuscitation bundle is associated with improved outcome [35]. According to this study, absence of lactate clearance during the first 24 hours is associated with mortality in septic ICU patients and should lead to therapy intensification, even in patients who reach standard hemodynamic target.

Several limitations should be considered to interpret this study. First, it was an observational analysis whose results support an association and not necessarily causation. Second, data come from a single center and institution-specific variables may have influenced the present results. Moreover, in the current cohort, following international recommendations [4], patients with a low $\mathrm{ScvO}_{2}$ have received either dobutamine or transfusion as adapted and these therapeutic-adaptations may have limited our ability to confirm the value of $\mathrm{ScvO}_{2}$ as a prognostic factor.

In conclusion, during severe sepsis or septic shock, blood lactate concentration and lactate clearance are both predictive for 28-day mortality. Assessment of lactate clearance in the first 24 hours would be useful for tracking patients who remained at high risk of death despite achievement of recommended early goals determined by international recommendations. Protocols of prolonged lactate clearance-directed therapy should be evaluated in septic patients.

\section{Competing interests}

No financial support was required to perform the study. Authors declare no conflict of interest. This study was performed in the Department of Anesthesiology and Intensive Care, CHU Toulouse, Université Toulouse III Paul Sabatier, Faculté de Médecine Toulouse-Purpan, EA 4564-MATN, Institut Louis Bugnard (IFR 150), Toulouse F-31000, France.

\section{Authors' contributions}

$\mathrm{PM}$ and FV recorded all data and wrote the manuscript. AL and FF participated in the design of the study and performed the statistical analysis. AR, KA, OF and VM participated in its design and coordination and helped to draft the manuscript. All authors read and approved the final manuscript.

\section{Acknowledgements}

This study has been performed in the Department of Anesthesiology and Intensive Care, CHU Toulouse, Université Toulouse III Paul Sabatier, Faculté de MédecineToulouse-Purpan, EA 4564-MATN, Institut Louis Bugnard (IFR 150), Toulouse F-31000, France.

\section{Author details}

'Department of Anesthesiology and Intensive Care, CHU Toulouse, Université Toulouse III Paul Sabatier, Faculté de Médecine Toulouse-Rangueil, EA 4564MATN, Institut Louis Bugnard (IFR 150), c F-31000, France. ${ }^{2}$ Department of Anesthesiology and Intensive Care, CHU Nantes, Nantes, France.

Received: 23 May 2012 Accepted: 29 November 2012

Published: 12 February 2013

\section{References}

1. Chillet P: The definition and epidemiology of septic shock. Soins 2012, (766):32-33.

2. Jones AE, Brown MD, Trzeciak S, Shapiro NI, Garrett JS, Heffner AC, et al: The effect of a quantitative resuscitation strategy on mortality in patients with sepsis: a meta-analysis. Crit Care Med 2008, 36(10):2734-2739.

3. Rivers EP: Early goal-directed therapy in severe sepsis and septic shock: converting science to reality. Chest 2006, 129(2):217-218.

4. Dellinger RP, Levy MM, Carlet JM, Bion J, Parker MM, Jaeschke R, et al: Surviving Sepsis Campaign: international guidelines for management of severe sepsis and septic shock. Crit Care Med 2008, 36(1):296-327.

5. Levy MM, Dellinger RP, Townsend SR, Linde-Zwirble WT, Marshall JC, Bion J, et al: The Surviving Sepsis Campaign: results of an international guideline-based performance improvement program targeting severe sepsis. Crit Care Med 2010, 38(2):367-374.

6. Annane D, Cariou A, Maxime V, Azoulay E, D'Honneur G, Timsit JF, et al: Corticosteroid treatment and intensive insulin therapy for septic shock in adults: a randomized controlled trial. JAMA 2010, 303(4):341-348.

7. Vincent JL, Rello J, Marshall J, Silva E, Anzueto A, Martin CD, et al: International study of the prevalence and outcomes of infection in intensive care units. JAMA 2009, 302(21):2323-2329.

8. James JH, Luchette FA, McCarter FD, Fischer JE: Lactate is an unreliable indicator of tissue hypoxia in injury or sepsis. Lancet 1999, 354(9177):505-508.

9. Levraut J, Ciebiera JP, Chave S, Rabary O, Jambou P, Carles M, et al: Mild hyperlactatemia in stable septic patients is due to impaired lactate clearance rather than overproduction. Am J Respir Crit Care Med 1998, 157(4 Pt 1):1021-1026.

10. Levy B, Sadoune LO, Gelot AM, Bollaert PE, Nabet P, Larcan A: Evolution of lactate/pyruvate and arterial ketone body ratios in the early course of catecholamine-treated septic shock. Crit Care Med 2000, 28(1):114-119.

11. Rixen $\mathrm{D}$, Siegel $\mathrm{JH}$ : Bench-to-bedside review: oxygen debt and its metabolic correlates as quantifiers of the severity of hemorrhagic and post-traumatic shock. Crit Care 2005, 9(5):441-453.

12. Cochran A, Edelman LS, Saffle JR, Morris SE: The relationship of serum lactate and base deficit in burn patients to mortality. J Burn Care Res 2007, 28(2):231-240.

13. Koliski A, Cat I, Giraldi DJ, Cat ML: Blood lactate concentration as prognostic marker in critically ill children. J Pediatr (Rio J) 2005, 81(4):287-292.

14. Meregalli A, Oliveira RP, Friedman G: Occult hypoperfusion is associated with increased mortality in hemodynamically stable, high-risk, surgical patients. Crit Care 2004, 8(2):R60-R65.

15. Vitek V, Cowley RA: Blood lactate in the prognosis of various forms of shock. Ann Surg 1971, 173(2):308-313.

16. Nguyen HB, Rivers EP, Knoblich BP, Jacobsen G, Muzzin A, Ressler JA, et al: Early lactate clearance is associated with improved outcome in severe sepsis and septic shock. Crit Care Med 2004, 32(8):1637-1642.

17. Jones AE, Shapiro NI, Trzeciak S, Arnold RC, Claremont HA, Kline JA: Lactate clearance vs central venous oxygen saturation as goals of early sepsis therapy: a randomized clinical trial. JAMA 2010, 303(8):739-746.

18. Varpula M, Tallgren M, Saukkonen K, Voipio-Pulkki LM, Pettila V: Hemodynamic variables related to outcome in septic shock. Intensive Care Med 2005, 31(8):1066-1071.

19. Rivers E, Nguyen B, Havstad S, Ressler J, Muzzin A, Knoblich B, et al: Early goal-directed therapy in the treatment of severe sepsis and septic shock. N Engl J Med 2001, 345(19):1368-1377.

20. Vallee F, Vallet B, Mathe O, Parraguette J, Mari A, Silva S, et al: Central venous-to-arterial carbon dioxide difference: an additional target for 
goal-directed therapy in septic shock? Intensive Care Med 2008, 34(12):2218-2225.

21. Vallee F, Fourcade O, Marty P, Sanchez P, Samii K, Genestal M: The hemodynamic "target": a visual tool of goal-directed therapy for septic patients. Clinics (Sao Paulo) 2007, 62(4):447-454.

22. Textoris J, Fouche L, Wiramus S, Antonini F, Tho S, Martin C, et al: High central venous oxygen saturation in the latter stages of septic shock is associated with increased mortality. Crit Care 2011, 15(4):R176

23. Ince $C$, Sinaasappel M: Microcirculatory oxygenation and shunting in sepsis and shock. Crit Care Med 1999, 27(7):1369-1377.

24. Fink MP: Cytopathic hypoxia. Is oxygen use impaired in sepsis as a result of an acquired intrinsic derangement in cellular respiration? Crit Care Clin 2002, 18(1):165-175.

25. Ladakis $C$, Myrianthefs $P$, Karabinis A, Karatzas G, Dosios T, Fildissis $G$, et al: Central venous and mixed venous oxygen saturation in critically ill patients. Respiration 2001, 68(3):279-285.

26. Haase N, Perner A: Central venous oxygen saturation in septic shock-a marker of cardiac output, microvascular shunting and/or dysoxia? Crit Care 2011, 15(4):184.

27. Smith I, Kumar P, Molloy S, Rhodes A, Newman PJ, Grounds RM, et al: Base excess and lactate as prognostic indicators for patients admitted to intensive care. Intensive Care Med 2001, 27(1):74-83.

28. Bernardin G, Pradier C, Tiger F, Deloffre P, Mattei M: Blood pressure and arterial lactate level are early indicators of short-term survival in human septic shock. Intensive Care Med 1996, 22(1):17-25.

29. Friedman G, Berlot G, Kahn RJ, Vincent IL: Combined measurements of blood lactate concentrations and gastric intramucosal pH in patients with severe sepsis. Crit Care Med 1995, 23(7):1184-1193.

30. Marecaux G, Pinsky MR, Dupont E, Kahn RJ, Vincent JL: Blood lactate levels are better prognostic indicators than TNF and IL-6 levels in patients with septic shock. Intensive Care Med 1996, 22(5):404-408.

31. Bakker J, Gris P, Coffernils M, Kahn RJ, Vincent JL: Serial blood lactate levels can predict the development of multiple organ failure following septic shock. Am J Surg 1996, 171(2):221-226.

32. Donnino MW, Miller J, Goyal N, Loomba M, Sankey SS, Dolcourt B, et al: Effective lactate clearance is associated with improved outcome in postcardiac arrest patients. Resuscitation 2007, 75(2):229-234

33. Tian HH, Han SS, Lv CJ, Wang T, Li Z, Hao D, et al: The effect of early goal lactate clearance rate on the outcome of septic shock patients with severe pneumonia. Zhongguo Wei Zhong Bing Ji Jiu Yi Xue 2012, 24(1):42-45.

34. Jansen TC, van Bommel J, Schoonderbeek FJ, Sleeswijk Visser SJ, van der Klooster JM, Lima AP, et al: Early lactate-guided therapy in intensive care unit patients: a multicenter, open-label, randomized controlled trial. Am J Respir Crit Care Med 2010, 182(6):752-761.

35. Nguyen HB, Kuan WS, Batech M, Shrikhande P, Mahadevan M, Li CH, et al: Outcome effectiveness of the severe sepsis resuscitation bundle with addition of lactate clearance as a bundle item: a multi-national evaluation. Crit Care 2011, 15(5):R229.

doi:10.1186/2110-5820-3-3

Cite this article as: Marty et al.: Lactate clearance for death prediction in severe sepsis or septic shock patients during the first 24 hours in Intensive Care Unit: an observational study. Annals of Intensive Care 2013 3:3.

\section{Submit your manuscript to a SpringerOpen ${ }^{\odot}$ journal and benefit from:}

- Convenient online submission

- Rigorous peer review

- Immediate publication on acceptance

- Open access: articles freely available online

- High visibility within the field

- Retaining the copyright to your article 